January 2013

\title{
Further Reflections on Extinguishing the Fountainhead of Knowledge: A Call to Transition to the "Innovation Policy" Narrative in Patent Law
}

Simone Rose

Wake Forest University School of Law

\section{Recommended Citation}

Simone Rose, Further Reflections on Extinguishing the Fountainhead of Knowledge: A Call to Transition to the "Innovation Policy" Narrative in Patent Law, 66 SMU L. REV. 609 (2013)

https://scholar.smu.edu/smulr/vol66/iss3/6

This Article is brought to you for free and open access by the Law Journals at SMU Scholar. It has been accepted for inclusion in SMU Law Review by an authorized administrator of SMU Scholar. For more information, please visit http://digitalrepository.smu.edu. 


\title{
FuRTHER REFLECTIONS ON EXTINGUishing THE FountaINHEAD OF Knowledge: A Call to Transition to The "InNovation Policy" Narrative in Patent LaW
}

\author{
Simone Rose*
}

\begin{abstract}
Economists are unable to provide a clear answer to how effective the patent system is in encouraging innovation. At best, they point to certain sectors, such as pharmaceutical and biotechnology, which benefit from a robust patent scheme. Conversely, sectors such as software and, ironically at the same time, biotechnology may be harmed by an overly broad patent scheme.

The question emerges: Why do the various stakeholders in all industrial sectors, Congress, the Patent and Trademark Office ("PTO"), and the courts (in particular, the Federal Circuit) continue to center the development of patent law around the "innovation presumption" despite the lack of theoretical and empirical evidence to answer the fundamental question: Do patents actually create more incentive to innovate, more actual innovation, and hence more economic growth? Preparing for this Symposium on the Federal Circuit, innovation, and disruptive technologies has allowed me to reflect further on why it is necessary to challenge the innovation presumption and explore alternative paradigms, such as the use of innovation "policy levers" for this problematic narrative.
\end{abstract}

\section{INTRODUCTION}

"There is virtually unanimous agreement that the purpose of the patent system is to promote innovation. ..."1 [The Innovation Presumption]

"The rise of the knowledge economy has been accompanied, inter alia, by a large increase in the volume of research devoted to the economics of patents and the patent system. The growth in research reflects the increased

* Professor of Law, Wake Forest University School of Law. I would like to thank Timothy Davis, Tracy Coan, Christine Nero Coughlin, and A'Tolani Akinkuoto for their invaluable assistance in the preparation of this Article.

1. See Dan L. Burk \& Mark A. Lemley, Policy Levers in Patent Law, 89 VA. L. Rev. 1575,1580 (2003). 
economic importance of the property rights attached to the production and commercialization of new ideas." 2

I $\mathrm{N}$ the late 1990s, I was a young scholar, with close ties to my former patent prosecution practice. I firmly believed the Grand Narrative that "patents were the engines of innovation." 3 To affirm the necessity of viewing patents as property and tools for innovation, I provided a basic empirical demonstration of how patents positively impact the economy. ${ }^{4}$ My article introduced this topic in the context of Ayn Rand's controversial novel, "The Fountainhead," where the protagonist, architect Howard Roark, warns that the further marginalization of the individual's creativity and the right to reap the rewards for that creativity will stifle the core of the individual, resulting in an economically disadvantaged slave society. ${ }^{5}$ In my article, to substantiate the need for preserving the Fountainhead and broadly viewing patents as "innovation property" rather than "anticompetitive monopolies," I evaluated the relationship between the percentage of patents adjudicated as valid by appellate courts, the number of patents filed in the PTO, and the Gross Domestic Product (GDP). ${ }^{6}$

Because of the various components comprising GDP, ${ }^{7}$ it was difficult to substantiate a strong statistical correlation between the percentage of patents adjudicated as valid and GDP. There was, however, a direct correlation between patents adjudicated valid and patent applications filed (0.646 Pearsons, 0.660 rank correlation) ${ }^{8}$ Thus, we observed that within a

2. Bronwyn Hall \& Dietmar Harhoff, Recent Research on the Economics of Patents 3 (2006).

3. See generally Simone A. Rose, The Supreme Court and Patents: Moving Toward a "Postmodern" Vision of Progress?, 23 Fordham InTEll. Prop. Media \& ENT. L.J. (forthcoming), available at http://papers.ssrn.com/so13/papers.cfm?abstract_id=2153952.

4. Simone A. Rose, Patent "Monopolyphobia": A Means of Extinguishing the Fountainhead?, 49 CASE W. RES. L. Rev. 509 (1999).

5. Id. at $510-11$

6. Id. at 547 \& n.199. As noted in the article, I chose GDP over gross private domestic investment because I was only exploring a trend and a possible cause-and-effect link between patent protection and economic growth. I encouraged formally trained economists to follow up on this data with the proper logarithmic analysis to further verify the relationships, particularly with reference to gross domestic investment.

7. Specifically, GDP results from several variables, including, but not limited to, savings rates, exchange rates, savings, income, and government policy. See RICHARD LiPSEY \& Alec Chr'ysal, Economics 390, 432 (11th ed. 2001).

8. See Rose, supra note 3, at 548-51; see also id. at $558 \mathrm{fig}$. 1a. The Pearson's correlation is a preferred function to compare data sets to evaluate how direct the correlation is between data. It is an estimate of the population correlation coefficient. See AMIR D. Aczel, Complete Business Statistics 435-38 (3d ed. 1996). A Pearson's correlation coefficient of +1 means that there is a perfect and positive linear relationship between the two variables such that whenever one increases, the other variable also increases. Id. at 438. Similarly, the rank correlation is useful when one or more variables in question cannot be measured in the usual way. Id. at 663-64. The range utilized is from +1 to -1 . A positive rank correlation suggests that the variables are directly related, while a negative correlation suggests they are inversely related. Id. at 664 . The two extremes represent a perfect direct or inverse relationship, respectively. Id. Statistical independence would have a rank correlation of $0 . I d$. 
short time following a cycle of judicial hostility towards patents, the number of patent applications decreased. This led to the conclusion that negative judicial sentiment adversely affects patent filings. ${ }^{9}$ Not surprisingly, there was an even greater statistical correlation between percent change in GDP and percent change in patent applications filed ( 0.944 rank correlation and 0.887 Pearsons). ${ }^{10}$ Unfortunately, the data failed to substantiate which set of data establishes cause and effect. We suggested that, at best, this preliminary data established that patent filings, along with judicial views towards patents, impact economic growth to some degree. ${ }^{11}$ Economists, like Zvi Griliches of Harvard, similarly concluded that the data is inconclusive concerning the overall positive impact of innovation (patent procurement) on GDP. ${ }^{12}$

Interestingly, industry-specific statistical studies during this time found that for industries such as pharmaceuticals and chemicals, which rely heavily on patents for intellectual property protection, patent procurement increased the rate of innovation and had a substantial impact on those industries. ${ }^{13}$ For example, economists Francis Narin and Elliot Noma found correlations of 0.82 between expert opinion of pharmaceutical company technical strength and the number of U.S. patents granted to the companies. They further found correlations between 0.6 and 0.9 between increases in company profits and sales, and both patent citation frequency and concentration of company patents within a few classes. ${ }^{14}$ Nevertheless, the same economists were quick to state that they could not reach the same conclusions for other industries such as primary metals, electrical equipment, and motor vehicles, which rely much less on patent protection. ${ }^{15}$

As I matured in my scholarship, I began to question the accuracy and potential societal harm caused by the innovation presumption. I argued for adding limitations to patent law to provide a better balance between

To statistically substantiate our visual evaluation of the relationship in charts, we ran Pearson's calculations, rank correlations, and T-test confidence calculations to evaluate the relationships among patents adjudicated on appeal, patent applications filed, and GDP. We found a rank correlation of 0.660 and a Pearson's correlation of 0.646 . Since these numbers are both approaching +1.0 , they appear to indicate evidence of a direct relationship between patent validity adjudication and patents filed.

9. Rose, supra note 3 , at 551-52.

10. Id. at 551 (describing the results illustrated in Tables 3 and 4 , with correlation data at Table 5).

11. Id. at 552.

12. See Zvi Griliches, Patents: Recent Trends and Puzzles, Brookings PaPers: MiCROECONOMICS 291, 316-19 (1989). Griliches notes that "patent numbers are an imperfect index of inventive output ... [with] patent numbers leav[ing] us where we began, with a suggestive, but possibly misleading, puzzle." Id. at 316.

13. See generally Edwin Mansfield, Patents and Innovation: An Empirical Study, 32 MGMT. SCI. 173 (1986) (concluding that patent protection increased the rate of innovation for industries such as pharmaceuticals and chemicals, which rely primarily on patents for intellectual property protection).

14. See Francis Narin, Elliot Noma \& Ross Perry, Patents as Indicators of Corporate Technological Strength, 16 Res. POL'Y 143, 150 tbl.6 (1987).

15. See Mansfield, supra note 13, at 180; see also Griliches, supra note 12, at 303. 
access and innovation. ${ }^{16}$ Recently, I expanded upon a suggestion from Professor Margaret Chon concerning copyright law, ${ }^{17}$ and urged the development of a framework to discuss patent law from a postmodernist perspective. ${ }^{18}$ Such an approach allows us to go beyond the innovation presumption and consider other societal issues such as humanism, morality, and sustainability when developing and implementing patent law. ${ }^{19}$ In that piece, I also questioned whether the innovation presumption effectively fulfills the constitutional mandate to "promote the progress of Science [Copyright] and the useful arts [Patents]."20

Almost fourteen years have passed since my empirical analysis, and leading economists still conclude that neither the theoretical or empirical research provides a clear answer as to the effectiveness of the patent system in encouraging innovation. ${ }^{21}$ At best, economists point to certain sectors, such as pharmaceutical and biotechnology, which benefit from a robust patent scheme, while acknowledging that sectors such as software and ironically, in some cases, biotechnology, may be harmed by an overly broad patent scheme. ${ }^{22}$

Preparing for this symposium has allowed me to reflect on why stakeholders in all industrial sectors, Congress, and the courts (in particular, the Federal Circuit) continue to center the development of patent law around the innovation presumption, despite the lack of theoretical and empirical evidence to answer the fundamental question: Do more patents actually create more incentive to innovate, more actual innovation, and hence more economic growth? I explored why it is necessary to challenge the innovation presumption and evaluated alternative paradigms for this problematic narrative. This Article suggests three reasons why it is time to eliminate the innovation presumption and begin evaluating patent issues with an eye to specific industry or invention-centered "innovation policy."

16. See, e.g., Simone A. Rose, On Purple Pills, Stem Cells, and Other Market Failures. A Case for a Limited Compulsory Licensing Scheme for Patent Property, 48 How. L.J. 579 (2005); Simone A. Rose, Semiconductor Chips, Genes and Stem Cells: New Wine for New Bottles?, 38 AM. J.L. \& MED. 113 (2012).

17. See Margaret Chon, Postmodern "Progress": Reconsidering the Copyright and Patent Power, 43 DePaul L. Rev. 97 (1993) (advocating a postmodern view of progress that allows us to evaluate Congress's copyright and patent power "against a complex context of disparities in control over knowledge rather than simply against the provision of incentives to inventors").

18. See e.g., Rose, supra note 3.

19. See, e.g., id.

20. Id.

21. See e.g., Hall \& Harhoff, supra note 2 , at 12.

22. See e.g., James Bessen \& Eric Maskin, Sequential innovation, patents and imitation, 40 RAND J. ECON. 611, 611-12 (2009) (noting that within an industry such as software, which is based primarily on sequential and complementary innovation, weak patent protection may promote innovation whereas stronger patent protection would actually inhibit innovation); Burk \& Lemley, supra note 1, at 1683 ("Biotechnology then, is properly described in part by the anticommons theory (too many narrow patents must be aggregated to promote a viable product), and in part by prospect theory (a long and uncertain postinvention development process justifies strong control over inventions)."). 
First, there is a lack of empirical or theoretical evidence that patents broadly promote innovation. In fact, for industries relying on complementary technologies such as software, biotechnology, and semiconductors, patenting more likely impedes rather than promotes innovation. ${ }^{23}$ Nevertheless, in these very areas, industry stakeholders continue to improperly leverage the innovation presumption to persuade patent attorneys, the PTO, Congress, and the courts to broaden the scope of patentable subject matter without questioning whether protecting such subject matter will in fact promote innovation. ${ }^{24}$

Second, abandoning the innovation presumption allows the Federal Circuit to shift from the current framework of legal formalism and brightline rules to a "more nuanced and policy centered" analysis when evaluating patentability issues. ${ }^{25}$ As outlined by Dan Burk and Mark Lemley, the court can use legal principles such as $\S 101$ of the Patent Act's abstract idea exclusion or $\S 103$ 's nonobviousness requirement as "policy levers." 26 These levers are applied either broadly or narrowly depending on the factual context (e.g., specific nature of the invention) and whether patents positively or negatively impact innovation in that industry. ${ }^{27}$ The use of such policy levers would allow courts to conduct a more-balanced evaluation of patentability and related issues. Similarly, the wealth of policy and empirical analysis found in legal scholarship provides yet another avenue for courts to move beyond the innovation presumption and instead consider a wider range of policy concerns when applying patent law.

Finally, looking beyond the innovation presumption empowers Congress, the PTO, and courts to look more closely at "disruptive technologies," 28 such as biotechnology and software, which unexpectedly displaced earlier-established technologies, to determine how best to pro-

23. See, e.g., Bessen \& Maskin, supra note 22, at 611-12.

24. Stuart Macdonald, When Means Become Ends: Considering the Impact of Patent Strategy on Innovation, 16 Info. ECON. \& PoL'Y 135, 135-38 (2004); Peter S. Menell, Forty Years of Wondering in the Wilderness and No Closer to the Promised Land: Bilski's Superficial Textualism and the Missed Opportunity to Return Patent Law to Its Technology Mooring, 63 Stan. L. Rev. 1289, 1305-06 (2011).

25. As noted by Janet Mueller, patent scholars lament the rise of formalism in recent Federal Circuit decisions with the apparent preference for bright-line rules over "more nuanced, multi-factored, 'totality of the circumstances' standards." Professor Mueller and others argue that the "dynamic innovation environment" presented by patents begs for less formal rules and more dynamic and nuanced analysis. See Janet Mueller, The Evanescent Experimental Use Exemption from United States Patent Infringement Liability: Implications for University and Nonprofit Research and Development, 56 BAYLOR L. REV. 917, 963-65 (2004) (citing John R. Thomas, Formalism at the Federal Circuit, 52 AM. U. L. REv. 771, 792 (2003)). For a discussion of the Supreme Court's rejection of bright-line rules in the patent context and why bright-line rules fail to further "the innovation goals of patent law," see Sapna Kumar, The Accidental Agency? 65 FlA. L. Rev. 229, 253 (2013); Arti K. Rai, Engaging Facts and Policy: A Multi-Institutional Approach to Patent System Reform, 103 Colum. L. Rev. 1035, 1040, 1119-20 (2003).

26. See Burk \& Lemley, supra note 1 , at $1641-48$.

27. See id. at 1670 ("[P] olicy levers [such as $\S 101$ 's subject matter exclusions, the doctrine of equivalents, and experimental use] are properly understood as standards: legal principles that can be applied with sensitivity to the industry and the factual context of the cases before the court.").

28. See Clayton M. Christensen, The Innovators Dilemma (1997). 
tect these technologies within the constitutional mandate of promoting progress of the useful arts. ${ }^{29}$ Under this more-balanced paradigm, industry-specific policy groups within the PTO could use empirical, theoretical, and policy tools to develop more accurate and balanced patentability guidelines for disruptive technologies. Similarly, shifting from an innovation presumption patent paradigm to one that focuses more on industryspecific "innovation policy" would pave the way for Congress to tackle the difficult public-access/experimental use issues surrounding the patenting of software and basic biological research.

Although this Article addresses each of the three reasons for shifting from an innovation-presumption to an innovation policy based narrative, it focuses most heavily on the lack of evidence supporting the "Grand" innovation presumption. I will briefly address the other two reasons, but further research is required to give them the appropriate level of coverage.

I. Reason \#1: Despite the lack of concrete empirical or theoretical evidence that patents broadly promote innovation, industry stakeholders, courts, and the PTO continue to use the innovation presumption to gain unfair leverage over what constitutes patentable subject matter.

" $A$ first observation is that the sheer size and growth of the recent literature might lead one to assume that patents are an extremely important instrument of economic development and growth ... [b] ut this seems at odds with the weak evidence that patents serve as an incentive for innovation ...." 30

Notwithstanding an increase in the amount of research exploring the relationship between patent procurement and innovation, conflicting theoretical and empirical evidence persists on whether patent procurement positively impacts innovation. ${ }^{31}$ At best, patent procurement seems to promote innovation in select industries such as pharmaceutical, chemical, and medical devices, while potentially deterring innovation in others, such as software and semiconductors. ${ }^{32}$ For decades, leading economists have been using empirical data to challenge the innovation presumption that patents are the most effective mechanism to promote innovation. ${ }^{33}$

29. See U.S. Const. art. I, § 8, cl. 8. ("To promote the Progress of Science [Copyrights] and useful Arts [Patents], by securing for limited Times to Authors and Inventors the exclusive Right to their respective Writings and Discoveries.").

30. HALl \& HaRHOFF, supra note 2, at 35.

31. Id. at 35 ; see also Griliches, supra note 12, at 303 (concluding that the data is inconclusive concerning the overall positive impact of innovation (patent procurement) on GDP).

32. HALl \& HARHoFf, supra note 2, at 15 ("A third finding from the empirical literature is that if there is an increase in innovation due to patents, it is likely to be centered in the pharmaceutical, biotechnology, and medical instruments areas, and possibly specialty chemicals.").

33. For an example of an economist who views the innovation narrative as a "myth" promulgated by stakeholders for whom patent protection provides a distinct economic advantage, see Macdonald, supra note 24, at 135-38. For an example of economists who em- 
Early empirical research concluded that patent procurement stimulated innovation in only select U.S. industries. In 1986, Edwin Mansfield was one of the first economists to empirically evaluate the effect of patent procurement on the development and commercialization of inventions across numerous industries. ${ }^{34}$ Using a random sample of 100 manufacturing firms from twelve industries, he concluded that patent protection was essential for development or introduction of $30 \%$ or more of the inventions in only two industries-pharmaceuticals and chemicals. ${ }^{35}$ On the opposite end of the spectrum, patents had negligible or zero impact on innovation in a broad array of industries, including electrical equipment, instrument, office equipment, motor vehicles, and rubber and textiles. ${ }^{36}$ The data further indicated that within industries, firms that heavily invested in research and development $(R \& D)$ placed greater value on patent procurement than less research-intensive firms because the researchintensive firms typically produced inventions that "patents are relatively effective in protecting." 37

Remarkably, even in industries such as motor vehicles and electrical equipment, where patent procurement had no effect on innovation, at least half of the patentable inventions were patented due to perceived benefits of the strategic use of patents as bargaining chips to collect royalties and otherwise intimidate would-be imitators. ${ }^{38}$ In the end, Mansfield concluded that "[d]espite the fact that the patent system generally is defended at least partly on the grounds that it increases the rate of innovation, the present study indicates that its effects in this regard are very small in most of the industries we studied." 39

A 1987 study by Francis Narin and Elliot Noma on patents as indicators of corporate technological strength mirrors Mansfield's conclusion that the pharmaceutical industry is one of the few industries where there is a direct correlation between patent procurement and innovative pro-

pirically distinguish between inventions that are "static" for which patent procurement promotes innovation, and patents that are "sequential and complementary" for which patent procurement is more likely to deter innovation, see Bessen \& Maskin, supra note 22, at 612-13. See also Bronwyn Hall, Business Method Patents, InNovation, and Policy 16 (2003) (noting that only in industries where innovation is incremental, where "many different innovations must be combined to make a useful product," does the patent system become more detrimental to innovation). For a similar analysis that focuses on complex biopharmaceuticals, see Stu Woolman, et al., Evidence of Patent Thickets In Complex Biopharmaceutical Technologies, 53 IDEA 1, 1 (2013) (using empirical data to substantiate that "a patent thicket effect in the domain of complex biopharmaceutical technologies becomes quite pronounced when the potential seller must acquire a license from three or more patent owners").

34. Mansfield, supra note 13, at 174 (noting that the problem with earlier studies was that they focused on relatively few industries, such as pharmaceutical and chemical).

35. Id. at 175 tbl.1. Mansfield studied the following twelve industries between 1981 and 1983: (1) pharmaceuticals, (2) chemicals, (3) petroleum, (4) machinery, (5) fabricated metal products, (6) primary metals, (7) electrical equipment, (8) instruments, (9) office equipment, (10) motor vehicles, (11) rubber, and (12) textiles. Id.

36. $I d$.

37. Id at $175-76$.

38. Id. at 176-77 tbl.2.

39. Id. at 180 . 
ductivity..$^{40}$ Narin and Noma found an overall correlation of 0.82 between expert opinion of pharmaceutical company technical strength and the number of patents granted. ${ }^{41}$ They further reported correlations in the range of $0.6-0.9$ between increases in company profits and sales and both patent citation frequency and concentration on company patents within a few patent classes. ${ }^{42}$

In 1989, Harvard economist Zvi Griliches conducted a more comprehensive empirical analysis to explore the relationship between patent procurement, inventive activity, and productivity growth. ${ }^{43}$ His empirical study yielded a more complex and puzzling relationship. ${ }^{44}$ Griliches used his own data and data obtained from economist Bronwyn Hall to evaluate: (1) the number of patent applications and grants from 1880-1987; (2) the logarithmic relationship between U.S. patent applications, patents granted, and company-financed R\&D between 1953 and 1987; (3) actual and predicted patent grants and the number of patent examiners between 1947 and 1987 ; (4) the distribution of patents granted by year of application between 1966 and 1982 and time to year of grant; (5) the logarithmic relationship between domestic patent applications, real GNP, and GDP investment during this same time period; (6) the patents granted to select firms in the electronic, chemical, and automobile industries between 1968 and 1984; (7) the logarithmic relationship between multifactor productivity in the private business economy, and patent and R\&D capital stocks between 1947 and 1987; and (8) the percent of actual and simulated productivity growth between 1900 and 1988.45

Presumably, such a comprehensive data set would produce clear-cut conclusions concerning the impact of patent procurement on innovation and productivity growth in the United States. Yet, Griliches's results indicated that over a long period of time, patent numbers are an imperfect and puzzling index of inventive output and productivity growth for a variety of reasons. ${ }^{46}$ Regarding inventive activity, he observed that "the reach of any particular invention does not expand at the same rate as the growth of the overall economy, but only at the rate of growth of its own market." ${ }^{77}$ Griliches also established that neither patents granted nor inventive activity served as effective predictors of productivity growth because growth is due to a host of factors beyond invention, such as the quality of the labor force, economies of scale, and various reallocations of capital between assets and industries. ${ }^{48}$ As part of his study, Griliches questioned whether patent procurement itself accurately measures the rate of invention since patented inventions probably account for less than

40. See Narin, Noma \& Perry, supra note 14.

41. Id.

42. Id.

43. Griliches, supra note 11.

44. Id.

45. Id. at 292 fig.1, 293 fig.2, 294 fig.3, 295 tbl.1, 298 fig.4, 306 fig.5, 318 fig.6, 324 fig.1.

46. Id. at 319.

47. Id at 315 .

48. Id. at 316. 
half of all relevant advances and many industries seek alternate methods of protection ${ }^{49}$ and engage in selective patenting for strategic reasons, e.g., improving mousetrapping of other firms, rather than building better mousetraps. ${ }^{50}$ Griliches concludes that "the patent numbers leave us where we began, with a suggestive, but possibly misleading, puzzle." 51

Not surprisingly, economists in the twenty-first century continue to struggle with the narrative that patents are an effective mechanism for inducing innovation. ${ }^{52}$ For example, a 2000 Carnegie Mellon study by Wesley Cohen, Richard Nelson, and John Walsh demonstrated that except for the pharmaceutical industry, patents are not an effective mechanism for "appropriating returns to innovations." 53 Instead, the most effective and frequently used mechanisms by the majority of both product and process industries are secrecy, lead time, marketing strategies, and complementary capabilities. ${ }^{54}$ In 2012, Browyn Hall and Dietmar Harhoff provided a comprehensive survey of global studies concerning the impact of patent procurement on innovation and similarly concluded that the theoretical and empirical data is inconclusive on whether patents positively impact innovation. 55

Nevertheless, in the area of disruptive technologies, several economists have theoretically and empirically demonstrated that strong patent protection is likely to impede rather than promote innovation. Disruptive technologies are defined as technologies that have a disruptive effect or displace existing technologies. ${ }^{56}$ In 2009, economists James Bessen and

49. Id. (noting that patented inventions probably account for less than half of all relevant advances and "[ $[$ ]hat leaves at most a quarter of total productivity growth, and an unknown fraction of its fluctuations, to be attributed to patented invention").

50. Id. at 297-319.

51. Id. at 319.

52. HALL \& HARHOFF, supra note 2, at 35.

53. Wesley M. Cohen et al., Protecting Their Intellectual Assets: Approprability Conditions and Why U.S. Manufacturing Firms Patent (OR Not) 24 (2000), available at http://www.nber.org/papers/w7552; see also HALL \& HARHOFF, supra note 2, at 9 (noting that the Cohen et al. study "demonstrate[s] fairly clearly that patents are NOT among the important means to appropriate returns to innovation, except perhaps in the pharmaceutical industry"); id. at 15 (noting that "patents are not among the important means to appropriate returns to innovation, except perhaps in pharmaceuticals, medical devices, and some specialty chemicals").

54. COHEN ET AL., supra note 53, at 8,24-25. The authors distinguish that despite the formation of the Federal Circuit as the mandatory appellate court for patents in 1982, the primary purpose for patenting is not to increase industrial output or revenue, but instead to strategically enhance bargaining positions in negotiations and to prevent infringement suits.

55. See Hall \& Harhoff, supra note 2, at 12 ("It is fair to say that the theoretical work surveyed above does not deliver a clear message about the effectiveness of the patent system in encouraging innovation."); id. at 15 (stating that the limited empirical research demonstrates that any possible positive impacts on innovation from patents is likely to be found in the pharmaceutical, biotechnology, medical instrument and specialty chemical areas); id. at 15 (Hall and Harhoff further note that even where patents do not promote innovation, "firms and industries do respond to [the patenting practice] both by making use of the system and by sometimes tailoring their innovative strategies to its presence.").

56. See Motley Fool Staff, Roundtable: 5 Disruptive Technologies Leading the Next Medical Revolution (Feb. 26, 2013), http://www.fool.com/investing/general/2013/02/26/5-dis ruptive-technologies-leading-the-next-medical.aspx. Software and biotechnology are prime 
Eric Maskin studied the effect of strong patenting in the software, computer, and semiconductor industries, where innovation is both sequential (each invention builds upon its predecessor invention) and complementary (a variety of innovators take different research paths to ensure that a particular research goal is reached within the most efficient time). ${ }^{57}$ Here, the economists produced an economic model comparing two firms within a static industry, such as pharmaceuticals, against a dynamic model comparing two firms within a sequential industry, such as software. ${ }^{58}$ In both the static and dynamic models, the first firm innovates regardless of R\&D costs, while the second firm will only innovate if $R \& D$ costs are below a certain level. ${ }^{59}$

Under the static model, $\mathrm{R} \& \mathrm{D}$ is time-consuming and costly since this technology is not complementary, but totally innovative. Thus, the first firm will need robust patent protection to be able to recoup its costs and continue to innovate. Imitation is also costly under the static model since competition prevents the first firm from extracting the pricing level it needs to cover its initial R\&D expense, and it must sue to enforce its patent. The would-be imitator also incurs significant costs since it will have to defend against the first firm's patent claim and will likely have to stop production and pay monetary damages to the first firm. Because imitation was expensive to both the patentee and imitator, patenting not only deterred imitation, but encouraged would-be imitators to instead innovate themselves. Thus, patent protection led to increased R\&D within the static industry, which benefits both firms and society. ${ }^{60}$

In sharp contrast, the various propositions supported under Bessen and Maskin's more complex dynamic model demonstrate that when imitated, it is easier for an inventor to cover his cost of innovation in a sequential environment because complementary technology does not require "reinventing the wheel" with each invention, so R\&D costs are much

examples of disruptive technologies since they have displaced earlier mechanisms for achieving the same goals. Genome sequencing and RNA therapies, such as antisense drugs, are examples of biotechnological disruptive technologies. The Internet is probably the most striking example of software disruptive technology that displaced earlier means of communication. See CHRISTENSEN, supra note 27, at 19. In sharp contrast, pharmaceuticals in general are not disruptive technologies since they typically enhance, rather than displace previous treatment methods. For example, the newest generation cephalosporin antibiotic is able to treat bacterial infections faster and more efficiently. Harvey Simon, Urinary Tract Infection, U. MD. MED. CTR., (Sept. 17, 2012), http://umm.edu/health/medical/reports/arti cles/urinary-tract-infection. Similarly, new methods of chemotherapy basically improve rather than displace known strategies for attacking cancer cells. See, e.g., Guifa Xi et al., Convection-Enhanced Delivery of Nanodiamond Drug Delivery Platforms for Intracranial Tumar Treatment, Nanomedicine: Nanotechnology, Biology \& Med., Aug. 3, 2013 (forthcoming peer review article), available at http://dx.doi.org/10.1016/j.nano.2013.07.013.

57. See, e.g., Bessen \& Maskin, supra note 22, at 611-12. (explaining how the Lotus 1 2-3 spreadsheet built on VisiCalc and how Microsoft's Excel software built on Lotus are examples of sequential technology, and explaining the different approaches taken to voicerecognition software as examples of complementary inventions).

58. Id. at 614-22.

59. Id. at 615,621 .

60. Id. at 618-19. 
lower than for static industries. ${ }^{61}$ The economists distinguish that, unlike earlier studies, their model presumes that the imitator copies the first firm's technology to create a different product. ${ }^{62}$ Since the equilibrium level of $R \& D$ investment in a regime without patents is less than or equal to the social optimum, imitation can have the net effect of enhancing profits for all since it remains economically feasible for the first firm to continue innovating despite imitation. ${ }^{63}$ Moreover, the first firm also benefits from innovation since the imitator provides new ideas that raise the probability of follow-on innovations and raise future profits. ${ }^{64}$ Last but not least, the low cost of recouping from imitation makes it economically inefficient to apply funds to patent procurement and enforcement, because the diminishing returns will negatively impact future $R \& D$ funding. ${ }^{65}$ Hence, weak patent protection frequently promotes innovation in industries relying on sequential and complementary technology, while strong patent protection inhibits innovation. ${ }^{66}$ To empirically support their conclusions, Bessen and Maskin cite their earlier study demonstrating that firms obtaining the highest number of software patents when the PTO liberally granted these patents, "actually reduced their R\&D spending relative to sales after patent protection was strengthened." 67

Unlike software and semiconductors, biotechnology is one of the few "disruptive technologies" where one study supports the notion that patents can promote innovation. In 2003, economists Ashish Arora, Marco Cecaholi, and Wesley Cohen used a structural model combining survey responses and accounting data (on $R \& D$ ) to demonstrate that increasing the patent premium would likely lead to increased R\&D in most manufacturing sectors. ${ }^{68}$ The greatest increase occurred in medical instruments, followed by biotechnology and pharmaceuticals. ${ }^{69}$ Yet, a 2012 empirical study by Woolman, Fishman, and Fisher distinguishes that for complex biopharmaceuticals, the difficulties in clearing the overlapping patent rights needed to commercialize these invention creates "the patent

61. Id. at 625 .

62. Id. at 613 ("We depart from [the earlier] literature primarily in our model of competition ... [t] hat is, imitators do not product direct 'knockoffs,' but rather differentiated products.").

63. Id. at 623 .

64. Id. at 612-13. The authors further demonstrate in Proposition 6 that even if the first firm (inventor) does not gain from being imitated, he is still more likely to be able to cover the cost of innovation in a sequential, rather than a static, environment. Id.

65. Id. at $623-28$.

66. Id. at 628 ("The reflexive view that 'stronger is better' could well be too extreme; rather, a balanced approach seems called for. The ideal patent policy limits "knockoff" imitation, but allows developers who make similar, but potentially valuable complementary contributions.").

67. Id. (citing James Bessen \& Robert M. Hunt, An Empirical Look at Software PatenTs (2004)).

68. Ashish Arora et AL., $R \& D$ and the Patent Premium 1, 2, 35 (2003). The authors define "patent premium" as the difference in payoff to patented and unpatented inventions. Id. at 1 .

69. Hall \& HaRHoff, supra note 2, at 15 (discussing Arora et AL., supra note 68). 
thicket" effect, which impedes rather than promotes innovation. ${ }^{70}$ They statistically demonstrate that complex biopharmaceutical patents are likely to impede future innovation because sellers frequently have to navigate two or more "patent thickets" (existing overlapping patents covering the same area) that they must license to be able to manufacture and sell their downstream complex product. ${ }^{71}$ That study further found that if a would-be patentee has to acquire four or more licenses to develop and commercialize its product, the patent thicket effect is so pronounced that it becomes an insurmountable task to clear the necessary rights. ${ }^{72}$ These added costs clearly inhibit rather than promote innovation.

Woolman, Fishman, and Fisher's conclusions are consistent with the policy arguments made by legal commentators. Complex biopharmaceuticals, as well as most disruptive technologies, can be characterized as "cumulative innovations" because they rely on either complementary or overlapping technologies. ${ }^{73}$ Dan Burk and Mark Lemley contend that when inventions build upon either one or more complementary or overlapping patents, this increases the likelihood of market failures when inventors attempt to procure the rights needed to commercialize downstream products. ${ }^{74}$ Burk and Lemley separate the anticommons effect, which results from attempting to clear rights to complementary technology, from its "close cousin," the patent thicket, which results from attempting to clear rights in overlapping technology ${ }^{75}$

The "anticommons effect" occurs more frequently with biotechnology innovation since these downstream inventions typically build upon cumu-

70. See Woolman et al., supra note 33, at 1,7 (defining a patent thicket as "a dense web of overlapping intellectual property rights that a company must hack its way through in order to ... commercialize new technology").

71. Id. at 1 (outlining the following conclusions: a patent thicket effect is discernible when the inventor/commercializing entity must clear licenses from two or more prior patents to create a "downstream commercially viable product" and continues to become more pronounced as the number of necessary patent licenses increases. By the time the potential seller must acquire rights to use and sell the technology of four or more patents, the patent thicket effect is so strong that it "makes successful negotiations for all of the necessary licenses with the relevant patentees virtually impossible.").

72. Id.

73. Burk \& Lemley, supra note 1, at 1608-09. Later in the article, the authors outline software and semiconductors as examples of disruptive technology industries built upon overlapping technology and outline biotechnology as an example of a disruptive technology industry built on cumulative technology, such as basic biological research. See id. at 1687-95. The authors also discuss Kitch's prospect theory as the reason why a robust patent scheme stimulates innovation in the pharmaceutical industry. Id. at 1601-04. Here, inventive activity is typically generated by a single entity, rather than a collective group of researchers (as in the disruptive technology areas). Id. For this reason, strong patent rights should be awarded this single "coordinating entrepreneur" as a result of its singular and expensive research and development efforts. Id. at 615-16. Unlike patents for cumulative innovations, patents for inventions generated under the prospect theory should be "broad, stand alone, and confer almost total control over subsequent uses of the product." Id. The authors go on to opine that the "prospect vision of patents maps most closely onto invention in the pharmaceutical industry" because inventive activity is typically contained within a single entity, and it costs as much as $\$ 800$ million to bring a drug to market. $I d$. at 1616 .

74. See Burk \& Lemley, supra note 1, at 1600-13.

75. Id. at 1611-14. 
lative patents in related areas. ${ }^{76}$ According to Burk and Lemley, "aggregat[ing] such fragmented property rights entails high search and negotiation costs to locate and bargain with the many rights owners whose permissions are necessary to complete broader development."77 If all complementary patentees "hold out," commercializing the downstream biological product becomes cost-prohibitive and obstructs innovation. ${ }^{78}$ Similarly, Michael Heller and Rebecca Eisenberg contend that basic biological research, such as research on stem cells and isolated genes, is a misfit for patent law because the cognitive bias of patentees and potential licensees causes each to value upstream research tools differently. This inability to reach an "effective meeting of the minds" creates market failures for basic licensing agreements. Rather than having a commons of information created by effective licensing, we now have an "anticommons" where accessing knowledge becomes a Herculean task. ${ }^{79}$

In a slightly different context, "patent thickets" arise when a potential downstream producer requires access to multiple patents covering the same, rather than complementary, technology. Here, Burk and Lemley distinguish that the many layers of overlapping patents obtained at the various stages of research for these inventions create intellectual property clearance problems that delay the development of marketable downstream technology. ${ }^{80}$ Like the anticommons scenario, the potential seller must typically clear multiple patent rights from multiple owners. As demonstrated by Woolman, Fishman, and Fisher, the inability to efficiently clear these multiple overlapping rights frequently impedes rather than promotes innovation. ${ }^{81}$

In the face of decades of research that is unable to demonstrate that a robust patent scheme consistently induces innovation, how did the innovation presumption become a foundational premise of patent law? Economist Stuart Macdonald theorizes that we have been looking at things the wrong way. According to Macdonald, rather than patents being the engines of innovation, it is the strategic use of patents and the erroneous use of the innovation presumption by the pharmaceutical industry, the patent bar, and others that drives the ever-increasing numbers of patents without any empirical link to innovation. ${ }^{82} \mathrm{He}$ proposes that Congress and the courts fail to focus on when and how broad patent protection may inhibit innovation because the true purpose of the patent system has been "muffled by a host of ... interest groups" that reap extensive economic benefits from the existing innovation presumption. ${ }^{83}$ Fingers are often pointed at the pharmaceutical industry, a primary beneficiary of the innovation

76. Id. at $1624-25$.

77. Id. at 1611 .

78. Id.

79. See Michael A. Heller \& Rebecca Eisenberg, Can Patents Deter Innovation? The Anticommons in Biomedical Research, 280 Scr. 698 (1998).

80. Burk \& Lemley, supra note 1, at 1614-15.

81. See Woolman, Fishman \& Fisher, supra note 33, at 27.

82. See Macdonald, supra note 24.

83. See id. 
presumption that has been "disproportionately influential in decisions about the development of the system." 84

Legal commentators reach similar conclusions concerning the innovation presumption. Max Oppenheimer argues that industries benefitting from patent protection continuously fund lobbyists to persuade Congress to structure patent law with a focus on incentivizing innovation without paying adequate attention to "reserving to the public sufficient rights to guard against stifling future innovation." 85 Peter Menell laments that it was the lack of clear guidance from the Supreme Court that fueled the innovation presumption of "more patents equals more innovation" and more growth in disruptive technologies such as biotechnology, software, and business methods. ${ }^{86}$ Rather than engage in a constitutional discourse when evaluating patentability, courts are more likely to espouse the "innovation presumption" that we must broadly evaluate the patent right since patents are essential to incentivizing $R \& D$, and without them we would impede economic growth. ${ }^{87}$ The goal of incentivizing R\&D is then imbued with as much value as promoting progress of the useful arts. As a result, courts and the PTO continue to broaden what constitutes patenteligible subject matter under $\S 101$ to include "everything under the sun

84. Id. at 148. Macdonald's theory is supported by the PTO/ESA 2010 study illustrating the high rate of per-capita patenting across industries, including cumulative invention industries such as semiconductors and software, where over-patenting is more likely to impede rather than promote innovation. See Econ. \& Statistics Admin., InTellectual PROPERTY AND THE U.S. ECONOMY: INDUSTRIES IN FOCUS, (2012), available at http://www .uspto.gov/news/publications/IP_Report_March_2012.pdf (using data compiled by COHEN ET AL., supra note 53).

85. Max Stul Oppenheimer, The Time and Place for "Technology Shifting" Rights, 14 MARQ. INTELL. PROP. L. Rev. 269, 305 (2012). "[Under the mandate of the IP Clause,] . . there is room to reward innovators with exclusive rights, while still reserving to the public sufficient rights to guard against stifling future innovation. In recent attempts to strike the balance, Congress has tended to focus on the motivation to innovate the [incentive] side of the balance and paid less attention to the impediment to the innovation side, perhaps because innovators include well-funded lobbyists ...." Id. at 273.

86. Menell, supra note 24 , at $1305-06$ (stating that developers of new technologies often assumed that robust patent portfolio was crucial to effectively competing in the industry, attracting investors, and economic growth, and that, as a result, patent lawyers, corporations, and trade policy groups all pushed for patents as the focal point for industrial growth).

87. See, e.g., Kewanee Oil Co. v. Bicron Corp., 416 U.S. 470, 480 (1974) ("The patent laws promote this progress [from the IP clause mandate] by offering a right of exclusion for a limited period as an incentive to inventors to risk the often enormous costs in terms of time, research, and development. The productive effort thereby fostered will have a positive effect on society through the introduction of new products and processes of manufacture into the economy, and the emanations by way of increased employment and better lives for our citizens."); see also Diamond v. Chakrabarty, 447 U.S. 303, 315 (1980) ("The subject-matter provisions of the patent law have been cast in broad terms to fulfill the constitutional and statutory goal of promoting the 'the Progress of Science and the useful Arts' with all that means for the social and economic benefits envisioned by Jefferson."); Ass'n for Molecular Pathology v. U.S. Patent \& Trademark Office, 653 F.3d 1329, 1358-81 (Fed. Cir. 2011) (Moore, J., concurring) (arguing that patent protection for genomic material, including isolated genes is crucial for continued innovation and economic growth of the biotechnology industry), vacated sub nom. Ass'n for Molecular Pathology v. Myriad Genetics, Inc., 132 S. Ct. 1794 (2012), aff'd in part, rev'd in part, 689 F.3d 1303 (Fed. Cir. 2012), aff'd in part, rev'd in part, 133 S. Ct. 2107 (2013). 
as long as it is made by man" that is useful, novel, and non-obvious, and that meets the written description and enablement requirements. ${ }^{88}$ For courts, this has resulted in an unprecedented expansion of the boundaries of subject matter for disruptive technologies such as software, computer implemented business methods, and biotechnology. Not surprisingly, the Federal Circuit was often the pro-patentee court that expanded the subject-matter boundaries with sustained optimism..$^{89}$

At the same time, the innovation presumption of "more patents, more innovation" and economic growth ${ }^{90}$ led to a patent-centric view with patent lawyers leading the charge for corporate, industry, and trade-policy groups. ${ }^{91}$ Menell points out that the patent-centric view was destined to and indeed ultimately permeated "the executive, legislative and judicial arenas." $92 \mathrm{He}$ notes that the decision to provide patent protection for software was made without any empirical evidence that a robust patent scheme would enhance innovation in this area. ${ }^{93}$ Similarly, because the pharmaceutical industry was one of the first stakeholders to invest in biotechnology innovation, it was natural for the innovation presumption to flourish when evaluating patentability of this subject matter. Indeed, it is no surprise that the PTO drafted broad guidelines concerning the patentability of basic biological research such as isolated genes in the 1980s

88. See, e.g., In re Allapat, 33 F. 3d 1526, 1542 (Fed. Cir. 1994), abrogated by In re Bilski, 545 F.3d 943 (Fed. Cir. 2008). As pointed out by many commentators and a few courts, the committee report went on to include the limitation that anything under the sun made by man is subject to $\S 101$ and the remaining requirements of the Patent Act. See S. Rep. No. 1979, at 5 (1952); H.R. Rep. No. 1923, at 6 (1952).

89. See Menell, supra note 24, at 1305-07 (arguing that "public choice theory and empirical evidence suggest that the Federal Circuit, as a court specializing in patent adjudication, would be pro-patentee and inclined toward expanding the scope of patentable subject matter"). The recent line of biotechnology cases decided by the Federal Circuit, such as Ass'n for Molecular Pathology v. U.S. Patent and Trademark Office, 653 F.3d (Fed. Cir. 2011), and Mayo Collaborative Services v. Prometheus Laboratories, Inc., 132 S. Ct. 1289 (2012), as well as the latest computer-implemented business method case CLS Bank International v. Alice Corp., 685 F.3d 1341 (Fed. Cir. 2012), affd, 717 F.3d 1269 (Fed. Cir. 2013) (en banc), seem to support the pro-patent view of the Federal Circuit when deciding subject matter eligibility cases. See also Menell, supra note 24, at 1305-07.

90. Menell describes this modernist platform as "more patents equal more innovation." Menell, supra note 24 , at $1305-06$. He also argues that "public choice theory and empirical evidence suggest that the Federal Circuit, as a court specializing in patent adjudication would be pro-patentee and inclined toward expanding the scope of patentable subject matter." Id. at 1306-07; see also Graeme B. Dinwoodie \& Rochelle C. Dreyfuss, Patenting Science: Protecting the Domain of Accessible Knowledge, in THE FUTURE OF THE Public Domain: Identifying The Commons In Information Law 192, 209 (Lucie Guibault \& P. Bernt Hugenholtz eds., 2006) (expressing the view that "the continued patenting of upstream bioproducts, which are more like scientific principles than inventions, is a prime example of the Federal Circuit's patent dominated view on innovation").

91. See Menell, supra note 23, at 1305.

92. Id. at 1306 (quoting Diamond v. Diehr, 450 U.S. 175, 217 (1981) (Stevens, J., dissenting) (observing that in Gottschalk v. Benson, 409 U.S. 63 (1972), Parker v. Flook, 437 U.S. 584 (1978), and Diamond v. Diehr, 450 U.S. 175 (1981), "the spokesmen for the organized patent bar have uniformly favored patentability and industry representatives have taken positions properly motivated by their economic self-interests, and [n]ot withstanding fervent argument that patent protection is essential for the growth of the software industry, commentators have noted that this industry is growing by leaps and bounds without it").

93. Id. at $1306-07$. 
without considering the potential anticommons effect. ${ }^{94}$ This unfair leverage of the innovation presumption by stakeholders, courts, and the PTO, combined with the lack of concrete evidence that patents are indeed the most efficient mechanism to induce innovation, is enough to abandon this presumption and move to a more-balanced paradigm, such as focusing on industry or invention-specific innovation policy.

II. Reason \#2: Abandoning the innovation presumption allows the Federal Circuit to shift from its current framework of formalism and brightline rules to "more nuanced and policy centered" analysis.

"Despite the seeming attractiveness of precise rules, nuanced and flexible standards are generally more appropriate for the dynamic innovation environment confronted by the Federal Circuit." 95

Scholars frequently comment on the rise of formalism in the Federal Circuit and its adoption of bright-line rules in lieu of "more nuanced, multi-factored, 'totality of the circumstances' standards." Court has repeatedly warned the Federal Circuit against relying on bright-line rules when applying patent law. As early as 1997, the Court held that the established "function, way, result" test was not the sole test for determining patent infringement under the doctrine of equivalence..$^{97}$ Instead, the Federal Circuit was admonished to evaluate equivalence on a case-by-case basis focusing on whether the accused product or process "contain[s] elements identical or equivalent to each claimed element of the patented invention." 98 The Court reasoned that broadening the linguistic framework allows the Federal Circuit to continuously refine the test based on the particular factual context. ${ }^{99}$

Similarly, in 2007, the Court began its analysis of whether the "teaching, suggestion, and motivation" (TSM) test was the correct test for evaluating obviousness under $\S 103$ of the Patent Act by noting: "We begin by rejecting the rigid approach of the Court of Appeals [for the Federal Circuit]." 100 The Court took a more holistic approach by reasoning that "the diversity of inventive pursuits and of modern technology counsels against

94. See Utility Examination Guidelines, 66 Fed. Reg. 1092, 1093 (Jan. 5, 2001) (using the "everything under the sun made by man is patentable" sentiment, without any detailed legal analysis or limitations, to sweepingly assert that isolated genes constitute patent-eligible subject matter under $\S 101$ of the Patent Act because "[a]n isolated and purified DNA molecule ... does not occur in that isolated [chemical] form in nature"). According to the Guidelines, isolated genes are thus patentable under $\S 101$ as long as they meet the remaining statutory requirements of $\$ \S 102,103$, and 112 .

95. Mueller, supra note 25 , at 965.

96. Id. at 963-64; see also Kumar, supra note 25, at 249; Rai, supra note 25.

97. See Warner-Jenkinson Co., Inc. v. Hilton Davis Chem. Co., 520 U.S. 17 (1997).

98. See id. at 39-40 (holding that the "[e]ssential inquiry under doctrine of equivalents is whether accused product or process contains element identical or equivalent to each claimed element of patented invention")

99. Id.

100. KSR Int'l Co. v. Teleflex Inc., 550 U.S. 398, 415 (2007) (rejecting the Federal Circuit's rigid application of the TSM test as inconsistent with the expansive and flexible approach set forth by the Court). 
limiting the analysis" of obviousness to a rigid and mandatory formula. ${ }^{101}$ It then outlined the following factors relevant to determining the motivation to combine references: (1) the interrelated teachings of multiple patents; (2) the effects of demands known to the design community or present in the marketplace; (3) and the background knowledge and skill of the person of ordinary skill in the art. ${ }^{102}$ More recently, the Supreme Court cautioned against the use of bright-line rules to evaluate patentability when it held that the machine-or-transformation test was not the sole test for evaluating whether a claimed invention was a patent-ineligible abstract idea or protectable subject matter under $\S 101$ of the Patent Act. ${ }^{103}$

Arti Rai and Janice Mueller both argue that the use of bright-line tests inhibit the ability of the Federal Circuit to follow the Supreme Court's lead and to fully grasp and balance all of the dynamics in the "innovative environment" of patent law. ${ }^{104}$ They further posit that formalism prevents the court from taking the time to consider how a particular factual context or innovation policy might shape the analysis. ${ }^{105}$ Both observe that moving away from formalism would allow courts to follow the "holistic" trend of the Supreme Court and apply a more "nuanced and policycentered analysis" when applying patent law. ${ }^{106}$

Scholars, Burk and Lemley, propose the use of patent legal principles, such as the doctrine of equivalence, $\S 101$ 's abstract idea exclusion, and $\S 103$ 's nonobviousness requirement as "policy levers" to ensure a balanced application of patent law. ${ }^{107}$ They contend that courts could either broadly or narrowly apply these doctrines depending on the factual context (e.g. specific nature of the invention) and whether patents positively or negatively impact innovation in that industry. ${ }^{108}$ For example, when evaluating biotechnology patents, they recommend that courts apply $\S 103$ 's obviousness analysis broadly and $\S 112$ 's disclosure requirements

101. Id. at 418 .

102. Id. at 401 .

103. Bilski v. Kappos, 130 S. Ct. 3218,3226 (2010) (noting that "[a]dopting the machine-or-transformation test as the sole test for what constitutes a 'process' (as opposed to just an important and useful clue) violates" the statutory principles set forth in $\$ 101$ ).

104. See Mueller, supra note 25, at 965; Rai, supra note 25, at 1115-23.

105. Mueller, supra note 25, at 963-66; Rai, supra note 25, at 1037.

106. Rai, supra note 25, at 1103-06. Burk and Lemley also take this position and see formalism as a problem for the Federal Circuit. See, e.g., Burk \& Lemley, supra note 1, at 1673 (quoting Jay Thomas that "the unifying theme in Federal Circuit jurisprudence over the last ten years is a shift toward simple rules and legal formalism"). See id. 1673 at n.377 (noting opposite view by scholars such as Wagner, who prefers formalism since it provides greater certainty); see also Kumar, supra note 25, at 253-57 (citing Rai, supra note 25, and others and discussing the rise of formalism in recent Federal Circuit decisions and discussing the quasi-agency behavior of this court when deciding cases).

107. Burk \& Lemley, supra note 1 , at 1670.

108. See id. ("[P]olicy levers [such as $\S 101$ 's subject matter exclusions, the doctrine of equivalents and experimental use] are properly understood as standards: legal principles that can be applied with sensitivity to the industry and the factual context of the case before the court."). The authors cite $\S 101$ utility's requirement, experimental use, the validity presumption, and even injunctions as additional levers that may be applied based on the particular industry or invention. Id. at 1644-68. 
narrowly since doing so will "solve the anticommons problem often identified with biotechnology while at the same time boosting incentives to innovate." 109 For basic biological research, I suggest adding $§ 101$ 's law of nature exclusion as an additional "policy lever" to address anticommons concerns. Had the Federal Circuit been willing to relinquish its formalist approach, use of the "law of nature" exclusion as a policy lever could have produced a more-balanced holding in the controversial breast-cancer gene case, Ass'n for Molecular Pathology v. U.S. Patent and Trademark Office (commonly known as the Myriad case). ${ }^{110}$

Myriad provides the most recent illustration of the Federal Circuit's overreliance on bright-line rules and the innovation presumption. ${ }^{111}$ In Myriad, the Federal Circuit adopted the PTO Guidelines' bright-line conclusion that all isolated genes should be treated as "chemical compounds" 112 rather than as "biological information," and concluded that the BRCA 1 and BRCA 2 isolated genes constituted patent-eligible subject matter. ${ }^{113}$ Judge Lourie, writing for the majority, held that the isolated genes and the human-engineered, isolated cDNA gene sequences were patent-eligible subject matter. ${ }^{114} \mathrm{He}$ reasoned that the breaking of chemical bonds during the isolation process produces genetic material that constitutes a "distinct chemical entity" that is markedly different from the original product of nature. ${ }^{115}$ Because isolated genes are smaller and chemically-altered, and, therefore, are markedly different from their naturally occurring counterparts, they qualify as patent-eligible subject

109. Id. at 1682. Prior to this, the authors establish the innovation "duality" of biotechnology. For many inventions, the high cost of $R \& D$ and the numerous risks involved in bringing these products warrant a strong "incentive-based" patent regime. On the other hand, they distinguish that for basic biological research (such as DNA research), the anticommons effect makes robust patent protection problematic. They argue that their "alternative approach" of having one policy lever applied broadly (obviousness) and one narrowly (disclosure) provides an adequate policy balancing of both concerns. "This calibration of patent frequency and scope seems to be the proper response to the anticommons concern found in much of the biotechnology literature." Id. at 1675-82.

110. 653 F.3d 1329, 1333-34, (Fed. Cir. 2011). The case is referred to as the "Myriad" case since the exclusive licensee of the patent was Myriad Genetics, who ultimately was the respondent when the petition for certiorari was filed with the Supreme Court. See Petition For a Writ of Certiorari, Ass'n for Molecular Pathology v. Myriad Genetics, 133 S. Ct. 2107 (2013) (No. 12-398).

111. Id.

112. The genes-as-information view was espoused by the lower court and by Judge Bryson in his Federal Circuit dissent. See id. at 1375-78 (Bryson, J., dissenting) For an article discussing the opposing scientific and legal scholarly views of genes as information versus as chemical compounds, see Allen K. Yu, Within Subject Matter Eligibility-A Disease and $A$ Cure, 84 S. CAL. L. Rev. 387, 410 (2011).

113. See Ass'n for Molecular Pathology, 653 F.3d at 1354 (noting that the "decision that isolated DNA molecules are patent eligible comports with the longstanding practice of the PTO").

114. Id. at 1358. The Federal Circuit, applying Bilski, reversed the lower court on the method claims in Myriad, finding that all but one was patentable. Invalidity was upheld only for claims directed to comparing or analyzing DNA sequences, because they included no transformative steps and covered only ineligible abstract, mental steps. See id. at 1334.

115. Id. at 1352 ("Thus, when cleaved, an isolated DNA molecule is not a purified form of a natural material, but a distinct chemical entity."). 
matter under Diamond v. Chakrabarty. ${ }^{116}$

As part of the Myriad opinion, Judge Lourie concedes that biologists may legitimately take the contrary view that since the basic isolated BRCA $1 / 2$ genes have the same nucleotide sequence as their "native counterparts" (and must have them to carry out the invention's utility of detecting genetic mutations linked to certain breast and ovarian cancers), they are not markedly different and thus are patent-ineligible products of nature under $\S 101 .{ }^{117}$ Yet, Judge Lourie maintains that the court must give great weight to the PTO's long-standing position since 2001 that isolated DNA molecules are patent-eligible. ${ }^{118}$ Judge Kimberly Moore, in her concurring opinion, agrees with Judge Lourie and reinforces that the court's conclusion was based on the innovation presumption. ${ }^{119}$ She reasons that biotechnology companies have relied on these guidelines to develop a significant genomic portfolio and that patent protection for genomic material is crucial for continued innovation and economic

116. More specifically, Judge Lourie opined that "[i]solated DNA has been cleaved (i.e. had covalent bonds in its backbone chemically severed) or synthesized to consist of just a fraction of the naturally occurring DNA molecule." Id. at 1351. As such, this cleaving and synthesizing "imparts on the isolated DNA a distinctive chemical identity from that possessed by the native DNA." Id. Judge Moore's concurrence further distinguishes that the isolated cDNA falls into a separate category since cDNA, although based on a naturally occurring RNA template, is totally human-engineered and has no naturally occurring counterpart. Id. at 1364 (Moore, J., concurring) ("The claimed isolated cDNA sequences are the creation of man, made using biological tools and the naturally occurring mRNA as a template.").

For a recent article agreeing with Judges Lourie and Moore but putting a slightly different spin on the Chakrabarty rule, see Janice M. Mueller, Facilitating Patient Access to Patent-Protected Genetic Testing, 6 J. BUs. \& TECH. L. 83 (2011). In a thought-provoking piece, Professor Mueller disagrees with the Myriad district court and argues that the Chakrabarty rule does not focus on the "marked difference" between the natural product and the isolated, purified product, but instead simply requires that the isolated product is the subject of human intervention or manipulation. I find this rationale problematic because the Court used the specific term "marked differences" in its holding. In fact, crucial to the Chakrabarty court's reasoning was the fact that Dr. Chakrabarty's bacteria could digest crude oil, a feature lacking in its naturally occurring counterpart. Id. This distinction is what aligns Chakrabarty with Funk Bros. Seed Co. v. Kalo Inoculant Co., 333 U.S. 127, 131 (1948).

In Funk Bros., although the patentee manipulated and mixed several species of noninhibitive root-nodule bacteria, the end-product was patent-ineligible subject matter since the human intervention did not result in a product that was biologically different from its naturally occurring counterpart. Id. Professor Mueller argues that there is no need to align Chakrabarty and Funk Bros. because Chakrabarty was decided under $\S 101$ 's subject matter requirements and Funk Bros. was decided on obviousness grounds. See Mueller, supra note, at 88. Although the Funk Bros. court uses the language "lacks inventiveness," its core holding refers to the root-nodule material as "no more than the handiwork of nature and hence [it] is not patentable." See Funk Bros., 333 U.S. at 131-33. I would therefore suggest that, at best, the Funk Bros. patents were invalidated on both subject-matter and obviousness grounds. Id. at 131. I posit that it is the subject-matter rejection that parallels Chakrabarty. Ass'n for Molecular Pathology states that isolated DNA is "markedly different" because it can be used in diagnostic tests or gene therapy, see Ass'n for Molecular Pathology, 653 F.3d at 1353-81, but this property is simply incidental to the DNA being ex vivo. The utility of the DNA lies in its naturally occurring capability to encode specific information.

117. See Ass'n for Molecular Pathology, 653 F.3d at 1358-51.

118. See id. at 1354-55.

119. See id. at 1378 (Moore, J., concurring). 
growth of the biotechnology industry. ${ }^{120}$

Arguably, by clinging to the innovation presumption in Myriad, the Federal Circuit missed a golden opportunity to follow the guidance of the Supreme Court in Mayo Collaborative Services v. Prometheus Laboratories, Inc., and broadly apply $\S 101$ to exclude the native BRCA $1 / 2$ genes as "patent-ineligible" subject matter. ${ }^{121}$ Judge Moore in her concurring opinion in Myriad introduces the policy concern of preserving the biotechnology industry's reliance on the PTO Guidelines with the inference that this has promoted innovation and economic growth for this industry. ${ }^{122}$ Although introducing policy concerns into the patentability analysis was indeed a step in the right direction, Judge Moore's concurrence was fatally flawed because it failed to consider the valid anticommons concerns addressed by numerous scholars ${ }^{123}$ and distinguish that validating the claims covering isolated native DNA could impede, rather than promote, innovation. ${ }^{124}$

Had the Federal Circuit taken an innovation policy approach, it would likely give the PTO Guidelines less weight in light of the broader innovation and access policies at stake and apply § 101's law of nature exclusion

120. Id. at 1368.

121. See 132 S. Ct. 1289 (2012).

122. Ass'n for Molecular Pathology, 653 F.3d at 1368. (Moore, J., concurring). Judge Moore quotes the following excerpt from the Supreme Court's opinion in Festo Corp. v. Kinzoku Kabushiki Col, 535 U.S. 722, 739 (2002): "This outpouring of scientific creativity, spurred by the patent system, reflects a substantial investment of time and money by the biotechnology industry to obtain property rights to DNA sequences." Ass'n for Molecular Pathology, 653 F.3d at 1368.

123. See, e.g., Clarisa Long, Proprietary Rights and Why Initial Allocations Matter, 49 EMORY L.J. 823 (2000) (outlining the following factors that surround basic research licensing and contribute to an exponential increase in market failures: excessive transactions costs, search costs, and enforcement costs.) Professor Long further argues that as one approaches the basic or building-block end of the spectrum, the ability to predict accurately the commercial viability of the technology and its future uses becomes speculative at best. Id. Since both parties lack this data, it becomes difficult to negotiate effectively a technology transfer agreement for future innovation of basic research. She cites the string of uncertainty surrounding genes and genes fragments as an example of potential market failures. Id. at 832; see also Burk \& Lemley, supra note 1, at 1610-14 (discussing the economic theories behind the scholarly debate on whether too much patent protection creates an "Anticommons"); Dinwoodie \& Dreyfuss, supra note 90, at 193, 206-07 (describing upstream patents as "patents that protect fundamental principles of knowledge"); Id. at 206-07 ("Firms specialized in focused upstream work need upstream patents to attract funding and protection against free riders . . . . These new patents potentially chill progress ... because they increase transaction costs, require heterogeneous licensors to agree to terms (which has proved very difficult), allow patentees to disguise coordinated actions that restrain competition, and pose formidable barriers to entry.").

Heller \& Eisenberg, supra note 79, at 698. For contrary views that biotech patents do not necessarily create an anticommons, see, for example, Jonathan Barnett, Property As Process: How Innovation Markets Select Innovation Regimes, 119 Y ALE L.J. 384, 428-31 (2009) (arguing that the data is inconclusive that biotech patents create 'anticommons' and positing that the market will go through phases and correct itself by limiting property rights to preserve an adequate balance between innovation and access). Barnett cites the semiconductor industry as an example of an industry that successfully went through these phases. See also Christopher M. Holman, Biotechnology's Prescription for Patent Reform, 5 J. Marshall Rev. Intell. Prop. L. 318, 327-31 (2006).

124. Ass'n for Molecular Pathology, 653 F.3d at 1340-44 (Moore, J., concurring). 
more equitably. ${ }^{125}$ Then, instead of applying the bright-line chemical compound rule for protecting isolated genes, the panel would more broadly apply the $\S 101$ law/product of nature exclusion and more accurately focus on the biological identity of native and isolated DNA.126 Since, from a biological perspective, isolated DNA is not "markedly different" from native DNA in the human body, it is patent-ineligible subject matter under $\S 101$ and Diamond $v$. Chakrabarty. ${ }^{127}$ This analysis is more in line with the Supreme Court's rationale in Mayo v. Prometheus, which the Federal Circuit was instructed to follow on remand. ${ }^{128}$ In Mayo, the Supreme Court provided a better example of going beyond the innovation presumption when it raised the policy issue that patenting a medical process that was more like a law of nature than not would potentially inhibit rather than promote innovation. ${ }^{129}$ In sum, the use of industry-specific policy levers such as $\S 101$ 's law-of-nature exclusion would allow the Federal Circuit to conduct a more nuanced and balanced evaluation of patent issues. This can only occur if the court becomes willing to surrender the innovation presumption and instead contemplate a wider range of industry/invention-specific policy concerns when applying patent law.

III. Reason \#3: Abandoning the innovation presumption and evaluating industry-specific "innovation policy" empowers the PTO and Congress to carefully consider how to best protect disruptive technologies under patent law.

"No institution has taken the responsibility for elaborating patent law in the fact-specific, policy-oriented manner that the language of the statute [the Patent Act] encourages."130

Third, and of equal significance for the Symposium's reflections on innovation and disruptive technologies, is my proposal that looking beyond the innovation presumption enables both the PTO and Congress to deal more effectively with "disruptive" 131 technologies such as biotechnology

125. Similarly, applying the $\S 101$ law-of-nature policy lever broadly would have prevented Judge Lourie from falsely distinguishing the patent-ineligible law-of-nature analysis for the process in Mayo as inapplicable to the isolated genes in Myriad because the isolated genes in Myriad were products of nature, rather than laws of nature. See id. at 1329.

126. This is exactly what Judge Bryson did in his part concurrence/dissent in both the original and remanded Myriad opinions. See id. at 1355 (Bryson, J., concurring in part and dissenting in part).

127. Id. at 1350.

128. See Rose, supra note 18 , at $22-23$.

129. Mayo, 132 S. Ct. at 1300-1302. I discuss this more fully in a forthcoming article. See Rose, supra note 3.

130. Arti Rai, supra note 25, at 1040-41.

131. Harvard Business School Professor Clayton M. Christensen distinguishes that a "disruptive technology" is one that is introduced in an established area of technology, then disrupts the existing technological paradigm and ultimately displaces it. In sharp contrast, a "sustaining technology" is one that contributes to an already existing technology rather than disrupting or replacing the existing technology. See CHRISTEnSEN, supra note 28. 
and software. ${ }^{132}$ I will briefly share my thoughts concerning this issue.

As noted during the Symposium, the PTO has formed a software partnership with the software community to improve the quality of softwarerelated patents. As part of this partnership, the PTO is conducting a variety of roundtables across the country (beginning with Silicon Valley), which will bring various regional stakeholders together to "share ideas, feedback, experiences, and insights on software-related patents." 133 The PTO also agreed to accept comments from interested parties on how to best enhance the quality of software-related patents. Several individuals, trade organizations, companies, and the Electronic Frontier Foundation submitted comments before the April 15, 2013 deadline. ${ }^{134}$ Google, the largest company to comment, suggested that the PTO should provide better guidelines and policies to address the clarity and over-breadth issues surrounding the boundaries of claim scope currently being experienced with software patents. ${ }^{135}$ Since the software industry benefits more from a less robust patent regime, paying attention to the input provided at the roundtables is not enough. I posit that the PTO must go one step further and evaluate the current economic data concerning complementary and sequential inventions such as software, as well as the "policy guidelines" for software provided by legal commentators. This gives the PTO a comprehensive set of innovation policy information that could then be used to draft rules and prosecution guidelines that adequately address the specific innovation and access policy issues raised by software.

Moving from the innovation presumption to an innovation policy paradigm also empowers Congress to look more closely at the access and innovation issues raised by disruptive technologies to explore potential limitations to the Patent Act that would more adequately balance the access and innovation issues at stake. Suggestions made for improving

132. See Motley Fool Staff, Roundtable: 5 Disruptive Technologies Leading the Next Medical Revolution (Feb. 26, 2013), http://www.fool.com/investing/general/2013/02/26/5-dis ruptive-technologies-leading-the-next-medical.aspx (stating that genome sequencing "falling from $\$ 95$ million in 1999 to as little as $\$ 7,700$ in 2012" and RNA therapeutics such as antisense drugs are examples of innovations that serve as "disruptive technologies" in 2013); see also U.S. Dep't. Health \& Human Servs., Fiscal Year 2013: Budget in Brief- Strengthening Health and Opportunity for All Americans 36 (2013), available at http://www.hhs.gov/budget/budget-brief-fy2013.pdf.

133. Software Partnership, USPTO, http://www.uspto.gov/patents/init_events/software partnership.jsp (last visited May 8, 2013).

134. See, e.g., Daryl Joseffer et al., Comments of Google, Inc., USPTO (Apr. 15, 2013), http://www.uspto.gov/patents/law/comments/sw-e_google_20130415.pdf.

135. Id. More specifically, Google stresses that $\S 112(\mathrm{f})$ is the source of most of the software patenting issues and the present situation of too many overly broad and vague patents being issued. They go on to suggest several changes to the MPEP and Patent Rules, as well as additional training for software examiners. Some proposed changes include: make it mandatory for examiners to determine if $\S 112$ applies to all software patent applications, rather than relying on the existing presumption that $\S 112(f)$ does not apply; only consider actual structure and disclosure, rather than intent to determine whether a software claim recites sufficient structure; require algorithms to be included with every business method and system claim, identify inputs from outputs, and include enough detail to allow someone to take the actions necessary to generate the outputs from the inputs. Id. at 3-11. 
access to upstream bioresearch include: (1) making subject matter eligibility a constitutional requirement where the person having ordinary skill in the art is used as a baseline to determine if the property scheme promotes or impedes progress; (2) adding compulsory licensing or fair use provisions to the Patent Act for basic research; (3) forming biotechnology patent pools; or (4) having petit patents for biotechnology inventions. ${ }^{136}$

Congress took a step in this direction during the legislative debates surrounding the America Invents Act, but failed to agree on a potential limitation that would allow access to patented genetic testing methods. ${ }^{137}$ Interestingly, a 2010 report issued by the Department of Health and Human Services recommended amending the Patent Act to include exemptions from liability if gene patents are used for research or patient care purposes. ${ }^{138}$

Also, due to the complementary and sequential nature of software inventions, a more robust experimental use exemption should allow for a level of access that is more in line with the innovation policy for this industry. Congress should follow Janice Mueller's proposal and apply new policy levers such as existing international patent law norms as a basis to broaden the experimental use exemption for patent infringement beyond

136. See, e.g., Rebecca S. Eisenberg, Noncompliance, Nonenforcement, Nonproblem? Rethinking the Anticommons in Biomedical Research, 45 Hous. L. Rev. 1059, 1093-98 (2008); Anna Bartow Laakmann, Restoring the Genetic Commons: A "Common Sense" Approach to Biotechnology Patents in the Wake of Ksr v. Teleflex, 14 Mich. Telecomm. \& TECH. L. Rev. 43, 71 (2007) (arguing for the Federal Circuit to broaden its view of the person of reasonable skill in the art, and for the Federal Circuit to apply a more 'flexible' approach, which will result in many upstream bioresearch tools being found obvious in light of prior art); David B. Resnick, A Biotechnology Patent Pool: An Idea Whose Time Has Come?, J. PHIL. ScI. \& L, Jan. 2003 (evaluating the viability of patent pools); Suzanne R. Swanson, The Patentability of Business Methods, Mathematical Algorithms and Computer-Related Inventions Afier the Decision by the Court of Appeals for the Federal Circuit in State Street, 8 FED. CiRcuIT B.J. 153, 177 (2009) (discussing commentary regarding "petit patent" protection); Allen K. Yu, Within Subject Matter Eligibility-A Disease and a Cure, 84 S. CAL. L. REv. 387, 428-30 (2011) (arguing for the "constitutional requirement" of subject matter eligibility); see also Toward a New Era of Intellectual Property: From Confrontation to Negotiation, The InNovation PARTNERship, (last visited May 8, 2013) http://www.theinnovationpartnership.org/data/ieg/documents/report/TIP_Report_E.pdf

(asserting that the old IP paradigm is broken for biotechnology products and arguing for "new IP" such as global implementation of alternative ways to stimulate innovation such as IP protection, plus health and environmental regulation, the judicial system, tax rules, public private partnerships to conduct upstream bioresearch, and publication of licensing information and sources of bioresearch to facilitate licensing); Maureen O'Rourke, Towards a Doctrine of Fair Use in Patent Law, 100 ColuM. L. REv. 1177, 1203-05 (2000) (advocating a fair use limitation for patent law that would require a five-part balancing test); Simone A. Rose, On Purple Pills, Stem Cells and Other Market Failures: A Case For A Limited Compulsory Licensing Scheme for Patent Property, 48 How. L.J. 579 (2005) (advocating a welldefined compulsory licensing provision, which can be utilized in cases of national emergency or where excessive transaction costs/market failures are established).

137. 157 Cong. Rec. H4420-06, 2011 WL 2472415 (proposing that the AIA include a limitation allowing for use of patented material for genetic testing). Unfortunately, this proposal was later withdrawn and replaced with a requirement that the PTO conduct a study on the impact of exclusive licenses for genetic material on the public.

138. See Advisory Comm. on Genetics, Health, \& Soc'y, Gene Patents and Licensing Practices and Their Impact on Patient Access to Genetic Tests, NIH (Apr. 2010), http:// oba.od.nih.gov/oba/sacghs/reports/SACGHS_patents_report_2010.pdf. 
its current "idle curiosity" limitation. ${ }^{139}$ This approach would allow for a better balance of access and innovation for this disruptive technology.

As argued, the PTO and Congress should relinquish the innovation presumption and adopt a more balanced innovation policy platform for evaluating patent law. This would motivate the PTO to draft rules and guidelines that align with the policy-oriented goals of the Patent Act. Similarly, Congress could use the innovation policies surrounding disruptive technologies to implement limitations on the Patent Act that better address public-access concerns.

\section{CONCLUSION}

It is time for stakeholders, Congress, the PTO, and courts to abandon the innovation presumption. First, there is little theoretical or empirical evidence supporting this problematic paradigm. In fact, for disruptive technologies, patents are often likely to impede rather than promote innovation. Second, abandoning the innovation presumption allows the Federal Circuit to move beyond formalism and adopt a more nuanced and policy-centered analysis when applying patent law. Last, but not least, looking beyond the innovation presumption empowers Congress and the PTO to carefully consider how to best protect disruptive technologies under patent law.

139. Madey v. Duke Univ., 307 F.3d 1351 (Fed. Cir. 2002); Mueller, supra note 25, at 969-73. 